medRxiv preprint doi: https://doi.org/10.1101/2020.06.25.20137323; this version posted June 27, 2020. The copyright holder for this preprint (which was not certified by peer review) is the author/funder, who has granted medRxiv a license to display the preprint in perpetuity.

All rights reserved. No reuse allowed without permission.

\title{
Factors Associated with Hospitalization and Disease Severity in a Racially and Ethnically Diverse Population of COVID-19 Patients
}

\author{
Angelico Mendy, ${ }^{1}$ Senu Apewokin, ${ }^{2}$ Anjanette A. Wells, ${ }^{3}$ Ardythe L. Morrow ${ }^{1}$ \\ ${ }^{1}$ Division of Epidemiology, Department of Environmental and Public Health Sciences, University \\ of Cincinnati College of Medicine, Cincinnati, OH, USA \\ ${ }^{2}$ Division of Infectious Diseases, Department of Medicine, University of Cincinnati College of \\ Medicine, Cincinnati, OH, USA \\ ${ }^{3}$ School of Social Work, College of Allied Health Sciences, University of Cincinnati, Cincinnati, \\ $O H, U S A$
}

Corresponding Author: $\quad$ Angelico Mendy, $\mathrm{MD}, \mathrm{PhD}$

Division of Epidemiology

Department of Environmental \& Public Health Sciences

The University of Cincinnati College of Medicine

160 Panzeca Way, Room 335

Cincinnati, $\mathrm{OH} 45267$

Phone: 513-558-7319

Email: angelico.mendy@uc.edu

Word count: Abstract: 258; Main text: 3,081 words; 5 Tables.

Funding: AM's contribution was partly funded by grant P30 ES006096 from the U.S. NIH. The project described was supported by the National Center for Advancing Translational Sciences of the NIH, under Award Number 5UL1TR001425-03. The content is solely the responsibility of the authors and does not necessarily represent the official views of the NIH.

Disclosures: Authors declare no relationship with industry or other relevant entities that might pose a conflict of interest in connection with the submitted article.

Author Contributions: AM contributed to the study concept and design, analysis and interpretation of data, and writing of the manuscript. SA, AAW, and ALM contributed to the interpretation of data and writing of the manuscript. AM takes full responsibility for the integrity of the dataset and the analysis results.

NOTE: This preprint reports new research that has not been certified by peer review and should not be used to guide clinical practice. 1 


\begin{abstract}
Background: The coronavirus disease (COVID-19) first identified in Wuhan in December 2019 became a pandemic within a few months of its discovery. The impact of COVID-19 is due to both its rapid spread and its severity, but the determinants of severity have not been fully delineated.
\end{abstract}

Objective: Identify factors associated with hospitalization and disease severity in a racially and ethnically diverse cohort of COVID-19 patients.

Methods: We analyzed data from COVID-19 patients diagnosed at the University of Cincinnati health system from March 13, 2020 to May 31, 2020. Severe COVID-19 was defined as admission to intensive care unit or death. Logistic regression modeling adjusted for covariates was used to identify the factors associated with hospitalization and severe COVID-19.

Results: Among the 689 COVID-19 patients included in our study, 29.2\% were non-Hispanic White, $25.5 \%$ were non-Hispanic Black, $32.5 \%$ were Hispanic, and $12.8 \%$ were of 'Other' race/ethnicity. About $31.3 \%$ of patients were hospitalized and $13.2 \%$ had severe disease. In adjusted analyses, the sociodemographic factors associated with hospitalization and/or disease severity included older age, non-Hispanic Black or Hispanic race/ethnicity (compared to nonHispanic White), and smoking. The following comorbidities: diabetes, hypercholesterolemia, asthma, COPD, chronic kidney disease, cardiovascular diseases, osteoarthritis, and vitamin D deficiency were associated with hospitalization and/or disease severity. Hematological disorders such as anemia, coagulation disorders, and thrombocytopenia were associated with both hospitalization and disease severity. 
medRxiv preprint doi: https://doi.org/10.1101/2020.06.25.20137323; this version posted June 27, 2020. The copyright holder for this preprint (which was not certified by peer review) is the author/funder, who has granted medRxiv a license to display the preprint in perpetuity.

All rights reserved. No reuse allowed without permission.

Conclusion: This study confirms race and ethnicity as predictors of severe COVID-19. It also

finds clinical risk factors for hospitalization and severe COVID-19 not previously identified such a vitamin D deficiency, hypercholesterolemia, osteoarthritis, and anemia. 
medRxiv preprint doi: https://doi.org/10.1101/2020.06.25.20137323; this version posted June 27, 2020. The copyright holder for this preprint (which was not certified by peer review) is the author/funder, who has granted medRxiv a license to display the preprint in perpetuity.

All rights reserved. No reuse allowed without permission.

\section{INTRODUCTION}

In December 2019, an outbreak of severe acute respiratory syndrome coronavirus-2

(SARS-CoV-2) pneumonia appeared in Wuhan and rapidly spread throughout the world causing more than 8 million infections and close to 450,000 deaths by June $2020 .^{1,2}$ Similar to previous coronaviruses, the newly identified virus is highly contagious; it is transmitted primarily through droplets and causes major outbreaks in the absence of adequate control measures. ${ }^{3}$ The manifestations of the coronavirus disease 2019 (COVID-19) caused by SARS-CoV-2 are widely variable. The infection is asymptomatic in some individuals, while in others, it causes symptoms ranging from dry cough and dyspnea to severe pneumonia with respiratory failure requiring admission in intensive care unit (ICU) and leading to death in severe cases. ${ }^{4,5}$

To date, a number of studies have investigated the predictors of severe COVID-19. Nevertheless, the sociodemographic and clinical factors that influence this disease course have not been fully defined. ${ }^{6-12}$ Whether asthma, a common respiratory illness affecting 1 in 12 American adults, is associated with disease severity in COVID-19 is still a matter of debate. ${ }^{13-17}$ Other important clinical factors remain understudied. For example, vitamin D deficiency affects 1 in 4 American adults, has an important immunologic role and has been suggested to increase the risk of SARS-CoV-2 infection. ${ }^{18}$ However, vitamin D deficiency has not been analyzed as a risk factor for severe COVID-19 among patients infected with SARS-CoV-2. Another understudied clinical factor is hypercholesterolemia, which affects 1 in 8 American adults; whether this condition has been reported to be associated with severe COVID-19 has not been analyzed in the published literature. ${ }^{19,20}$ Moreover, most of the research on the potential factors for severe COVID-19 have been conducted in China among Chinese patients which may limit 
medRxiv preprint doi: https://doi.org/10.1101/2020.06.25.20137323; this version posted June 27, 2020. The copyright holder for this preprint (which was not certified by peer review) is the author/funder, who has granted medRxiv a license to display the preprint in perpetuity.

All rights reserved. No reuse allowed without permission.

their generalizability to multi-ethnic populations. ${ }^{6-8,10}$ The reports that have included a racially diverse study sample are scant ${ }^{9,11,12,21}$ To address this gap in the literature, we aimed to determine the factors associated with hospitalization and disease severity in a racially and ethnically diverse population of COVID-19 patients by including some comorbidities missing in previous studies.

\section{METHODS}

\section{Data Source}

Data were extracted from the electronic medical record system for all COVID-19 patients diagnosed at the University of Cincinnati health system (UC Health) between March 13, 2020 to May 31, 2020. UC Health consists of 4 hospitals located in the Cincinnati metropolitan area and primary care and specialty clinics located in the states of Ohio, Kentucky, and Indiana. COVID19 diagnosis was defined as a positive nasopharyngeal reverse transcriptase polymerase chain reaction test for SARS-CoV-2. A total of 691 patients were diagnosed with COVID-19 and after exclusion of two patients who did not report their sex, 689 patients were included in our study.

\section{Variables}

Age at the time of COVID-19 diagnosis was calculated using patients date of birth. Sex, race/ethnicity, and smoking were self-reported. Comorbidities, as well as hematological disorders were defined using the $10^{\text {th }}$ revision of the International Classification of Diseases (ICD10) codes. The following comorbidities were well characterized in our data and were included in the study: obesity (E66), diabetes (E10 and E11), pure hypercholesterolemia (E78.0), 
medRxiv preprint doi: https://doi.org/10.1101/2020.06.25.20137323; this version posted June 27, 2020. The copyright holder for this preprint (which was not certified by peer review) is the author/funder, who has granted medRxiv a license to display the preprint in perpetuity.

All rights reserved. No reuse allowed without permission.

asthma (J45), chronic obstructive pulmonary disease (COPD) (J44), chronic kidney disease (N18), cardiovascular disease (I00-I99), neoplasm or a history of neoplasm (C00-D49), osteoarthritis (M15-M19), and vitamin D deficiency (E55). The hematological disorders we included were anemia (D50-D53 for nutritional anemia and D55-D59 for hemolytic anemia), coagulation defects, purpura and other hemorrhagic conditions (D65-D69), and thrombocytopenia (D69.6).

\section{Definition of Outcome Variables}

Hospitalization was defined as admission to the hospital for at least 24 consecutive hours. Disease severity was defined as admission to ICU and/or death during hospitalization. We also estimated the length of hospital stay among the COVID-19 patients who were hospitalized and successfully discharged. Those who died during hospitalization were excluded from the length of hospital stay analysis.

\section{Statistical Analysis}

Descriptive analyses were performed to summarize the characteristics of the COVID-19 patients overall and by hospitalization or disease severity status. Chi-square or Fisher's exact tests were used to estimate P-values for differences. The differences in the length of hospital stay were evaluated by means of Wilcoxon Rank Sum tests. The covariates-adjusted odds ratios (OR) and $95 \%$ confidence intervals (CI) for the associations of the patients' characteristics and comorbidities with hospitalization and disease severity were estimated by means of logistic regression analyses. We also performed multinomial logistic regressions to further stratify disease severity into admission to ICU and death. To identify the factors associated with length 
medRxiv preprint doi: https://doi.org/10.1101/2020.06.25.20137323; this version posted June 27, 2020. The copyright holder for this preprint (which was not certified by peer review) is the author/funder, who has granted medRxiv a license to display the preprint in perpetuity.

All rights reserved. No reuse allowed without permission.

of hospital stay, we fitted generalized linear models with a gamma distribution and a log link function which is similar in shape to the log-normal distribution and is robust to the outcome of length of hospital stay that was right skewed. ${ }^{22}$ The diagnostic plots for the generalized linear models showed that the assumptions were reasonably met and the regression coefficients $(\beta)$ along with the $95 \% \mathrm{CI}$ for the associations were reported. All the models were adjusted for age, sex, race/ethnicity, and cigarette smoking. The analyses were performed in SAS Version 9.4

(SAS Institute, Cary, NC) and two-sided p-values $<0.05$ were considered statistically significant in all analyses.

\section{RESULTS}

\section{Description of Study Population}

The 689 COVID-19 patients included in our study had a median age of 49.5 years (IQR: $35.2,67.5)$ and $53.0 \%$ were male. The race/ethnicity of study patients was $29.2 \%$ non-Hispanic White, 25.5\% non-Hispanic Black, 32.5\% Hispanic, and 12.8\% patients of 'Other' race/ethnicity. Cardiovascular disease was the most common comorbidity (49.5\%). The other comorbidities included diabetes $(24.7 \%)$, neoplasm or history of neoplasm $(19.7 \%)$, obesity $(18.6 \%)$, osteoarthritis (14.2\%), vitamin D deficiency (12.9\%), chronic kidney disease (11.8\%), asthma (10.2\%), COPD (8.8\%), and pure hypercholesterolemia (2.9\%). Hematological disorders were reported in $25.5 \%$ of patients for anemia, $8.0 \%$ for coagulation defect, and $5.4 \%$ thrombocytopenia (Table 1). 
medRxiv preprint doi: https://doi.org/10.1101/2020.06.25.20137323; this version posted June 27, 2020. The copyright holder for this preprint (which was not certified by peer review) is the author/funder, who has granted medRxiv a license to display the preprint in perpetuity.

All rights reserved. No reuse allowed without permission.

Two-hundred-sixteen (31.3\%) of COVID-19 patients were hospitalized and $91(13.2 \%)$ had the severe form of the disease. The COVID-19 patients who were hospitalized and/or had severe disease tended to be older, to be non-Hispanic Black, and to be past or current smokers, compared to those who were not hospitalized or free of severe disease. Hospitalized patients and those with severe disease also tended to have comorbidities such as obesity, diabetes, pure hypercholesterolemia, asthma, COPD, chronic kidney disease, cardiovascular disease, neoplasm or history of neoplasm, osteoarthritis, vitamin D deficiency, and hematological disorders (anemia, coagulation defect, and thrombocytopenia) (Table 1).

Among the COVID-19 patients who were hospitalized and survived ( $\mathrm{N}=191)$, the median length of hospital stay was 6.91 days (IQR: 3.27, 11.56) (Table 2). This duration was longer in adults aged 60 years or older compared with younger individuals, in non-Hispanic Whites and non-Hispanic Blacks, in patients with diabetes, asthma, COPD, chronic kidney disease, cardiovascular disease, neoplasm or history of neoplasm, vitamin D deficiency, or hematological disorders (anemia, coagulation defect, and thrombocythemia) (Table 2).

\section{Factors Associated with Hospitalization}

In adjusted analysis, the sociodemographic characteristics associated with hospitalization were age (OR: 1.36, 95\% CI: 1.22, 1.51 per 10-year increase), being non-Hispanic Black (OR: 2.23, 95\% CI: 1.41, 3.53) or Hispanic (OR: 1.91, 95\% CI: 1.11, 3.29) (compared to being nonHispanic White), and smoking (OR: 2.01, 95\% CI: 1.32, 3.06). The comorbidities associated with higher odds of hospitalization included diabetes (OR: 2.62, 95\% CI: 1.75, 3.90), pure hypercholesterolemia (OR: 9.30, 95\% CI: 2.02, 42.74), asthma (OR: 1.92, 95\% CI: 1.10, 3.35), chronic kidney disease (OR: 3.47, 95\% CI: 1.99, 6.07), cardiovascular disease (OR: 4.39, 95\% 
medRxiv preprint doi: https://doi.org/10.1101/2020.06.25.20137323; this version posted June 27, 2020. The copyright holder for this preprint (which was not certified by peer review) is the author/funder, who has granted medRxiv a license to display the preprint in perpetuity.

All rights reserved. No reuse allowed without permission.

CI: 2.75, 7.01), osteoarthritis (OR: 1.95, 95\% CI: 1.19, 3.19), and vitamin D deficiency (OR:

1.77, 95\% CI: 1.07, 2.93). The hematological disorders (anemia [OR: 2.59, 95\% CI: 1.72, 3.91],

coagulation defect [OR: 4.90, 95\% CI: 2.52, 9.56], and thrombocytopenia [OR: $6.03,95 \%$ CI:

2.64, 13.77]) were also associated with higher prevalence of hospitalization (Table 3).

\section{Factors Associated with Disease Severity}

\section{Disease severity}

The sociodemographic characteristics associated with severe COVID-19, after adjustment for covariates were age (OR: 1.27, 95\% CI: 1.11, 1.47) and being non-Hispanic black (OR: 3.15, 95\% CI: 1.71, 5.79) or Hispanic (OR: 2.78, 95\% CI: 1.29, 5.96) compared to nonHispanic White. Among the studied comorbidities, the odds of severe disease was higher in patients with diabetes (OR: 2.60, 95\% CI: 1.58, 4.28), pure hypercholesterolemia (OR: 3.47, 95\% CI: 1.30, 9.27), asthma (OR: 3.11, 95\% CI: 1.67, 5.80), COPD (OR: 2.85, 95\% CI: 1.41, 5.76), chronic kidney disease (OR: 5.35, 95\% CI: 2.92, 9.80), cardiovascular disease (OR: 6.11, 95\% CI: 3.00, 12.44), and vitamin D deficiency (OR: 1.95, 95\% CI: 1.07, 3.56). As for hospitalization, hematological disorders (anemia [OR: 4.12, 95\% CI: 2.44, 6.95], coagulation defect [OR: 5.39, 95\% CI: 2.85, 10.17], and thrombocytopenia [OR: 6.52, 95\% CI: 3.10, 13.73]) had a strong positive association with severe COVID-19 (Table 3).

\section{Admission to ICU and Death}

In multinomial analysis stratifying COVID-19 severity into admission to ICU and death, being non-Hispanic Black compared to being non-Hispanic White was the only sociodemographic characteristic associated with both admission to ICU (OR: 3.32, 95\% CI: 1.56, 
medRxiv preprint doi: https://doi.org/10.1101/2020.06.25.20137323; this version posted June 27, 2020. The copyright holder for this preprint (which was not certified by peer review) is the author/funder, who has granted medRxiv a license to display the preprint in perpetuity.

All rights reserved. No reuse allowed without permission.

7.07) and death (OR: 3.44, 95\% CI: 1.32, 9.00). Age was associated with increased death (OR:

1.94, 95\% CI: 1.47, 2.58 per 10-year increase), while Hispanics (OR: 3.44, 95\% CI: 1.42, 8.34)

and smokers (OR: 2.34, 95\% CI: 1.23, 4.46) had higher odds of admission to ICU.

Among comorbidities, odds of admission to ICU and death were both higher in patients with chronic kidney disease (OR: 5.63, 95\% CI: 2.72, 11.64 for admission to ICU and OR: 4.48, 95\% CI: 1.81, 11.08). The odds of admission to ICU were higher in diabetes (OR: 3.31, 95\% CI: 1.84, 5.96), pure hypercholesterolemia (OR: 3.77, 95\% CI: $1.25,11.36$ ), asthma (OR: 4.33, 95\% CI: 2.18, 8.58), COPD (OR: 4.26, 95\% CI: 1.87, 9.77), cardiovascular disease (OR: 5.59, 95\% CI: $2.57,12.14$ ), and vitamin D deficiency (OR: 2.55, 95\% CI: 1.28, 5.08).

The studied hematological disorders were associated with both admission to ICU (OR: 5.19, 95\% CI: 2.80, 9.65 for anemia, OR: 4.67, 95\% CI: $2.28,9.57$ for coagulation defects, and OR: 5.14, 95\% CI: 2.18, 12.09 for thrombocytopenia) and death (OR: 2.58, 95\% CI: 1.05, 6.38 for anemia, OR: $8.81,95 \%$ CI: $3.11,24.98$ for coagulation defect, and OR: $14.12,95 \%$ CI: 4.54, 43.84 for thrombocytopenia) (Table 4).

\section{Factors Associated with Length of Hospital Stay}

In adjusted analysis, male sex ( $\beta: 0.39,95 \% \mathrm{CI}: 0.16,0.62)$ had longer length of hospital stay while Hispanics ( $\beta$ : $-0.40,95 \%$ CI: $-0.74,-0.06)$ and participants of 'Other' race/ethnicity ( $\beta$ : $-0.65,95 \%$ CI: $-1.16,-0.14)$ had shorted length of hospital stay than non-Hispanic Whites. Comorbidities such as diabetes $(\beta: 0.50,95 \%$ CI: $0.26,0.74)$, asthma ( $\beta: 0.50,95 \%$ CI: 0.20, 0.81), COPD ( $\beta: 0.45,95 \%$ CI: 0.11, 0.79), cardiovascular disease ( $\beta: 0.40,95 \%$ CI: 0.10, 0.70), and vitamin D deficiency ( $\beta$ : $0.47,95 \%$ CI: $0.20,0.75)$ were associated with longer length of 
medRxiv preprint doi: https://doi.org/10.1101/2020.06.25.20137323; this version posted June 27, 2020. The copyright holder for this preprint (which was not certified by peer review) is the author/funder, who has granted medRxiv a license to display the preprint in perpetuity.

All rights reserved. No reuse allowed without permission.

hospital stay. Likewise, the hematological disorders (anemia [ $\beta$ : 0.38, 95\% CI: 0.14, 0.62], coagulation defect $[\beta: 0.57,95 \% \mathrm{CI}: 0.26,0.88]$, and thrombocytopenia $[\beta: 0.67,95 \%$ CI: 0.30 , 1.30]) were all associated with prolonged duration of hospital stay. (Table 5).

\section{DISCUSSION}

In this racially and ethnically diverse study population of COVID-19 patients, the sociodemographic characteristics associated with hospitalization and/or disease severity included older age, non-Hispanic Black or Hispanic race/ethnicity (compared to non-Hispanic Whites). Among the studied comorbidities, diabetes, pure hypercholesterolemia, asthma, COPD, chronic kidney disease, cardiovascular disease, osteoarthritis, and vitamin D deficiency were risk factors associated with hospitalization and/or severe COVID-19. Hematological disorders such as anemia, coagulation defects, and thrombocytopenia were associated with increased odds of both hospitalization and disease severity.

This report is one of a few epidemiological studies investigating the risk factors for disease severity in a racially and ethnically diverse sample of COVID-19 patients. In the UK, three studies analyzed data from the national Biobank and, consistent with our findings on nonHispanic Blacks, found excess hospitalizations in Blacks and Asians compared to Whites. ${ }^{23-25}$ In the US, five studies conducted among hospitalized COVID-19 patients observed an overrepresentation of non-Hispanic Blacks, with prevalences ranging from $51.0 \%$ to 83.2\%. ${ }^{9,12,25-27}$ However, the studies found that non-Hispanic Blacks were not at higher risk of severe disease or death compared to non-Hispanic Whites among hospitalized COVID-19 
medRxiv preprint doi: https://doi.org/10.1101/2020.06.25.20137323; this version posted June 27, 2020. The copyright holder for this preprint (which was not certified by peer review) is the author/funder, who has granted medRxiv a license to display the preprint in perpetuity.

All rights reserved. No reuse allowed without permission.

patients. $^{9,12,26-28}$ A large U.S. Department of Veterans Affairs study with 5,630 COVID-19 patients reported that non-Hispanic Blacks and Hispanics were more likely to test positive for COVID-19 than non-Hispanic Whites, but were not at higher risk of 30-day mortality. ${ }^{20}$ Of all of these studies, only one examined length of hospital stay as an outcome and it found no difference by race or ethnicity. ${ }^{12}$ Our results also suggested that although non-Hispanic Blacks and Hispanics were more likely to be hospitalized and to have severe COVID-19 than non-Hispanic Whites, length of hospital stay was not different between non-Hispanic Whites and non-Hispanic Blacks. It was even shorter in Hispanics and patients of 'Other' race/ethnicity than in nonHispanic Whites. It is possible that the higher death rates in non-Hispanic Blacks could have affected the length of hospital stay and explained the non-significant difference with nonHispanic whites. It is unclear, however why hospital stay was shorter in Hispanics and patients of 'Other' race/ethnicity.

Our results confirmed previous reports that older age and smoking as well as comorbidities such as diabetes, cardiovascular diseases, chronic kidney, COPD, coagulation defect, and thrombocytopenia are associated with hospitalization and/or severe COVID19. ${ }^{6,9,27,29,30}$ Consistent with the longer length of hospital stay noted in men in our analysis, it has been suggested that male sex may predispose to more severe COVID-19 due to hormonal factors. ${ }^{11,26}$ Males are known to have higher activity of angiotensin-converting enzymes 2 (ACE2), the receptors of which serve as an entry point for the SARS-CoV-2 in the alveolar epithelial cells and this could explain the increased risk of infection and disease severity in men previously reported in the literature. ${ }^{31}$ Another hypothesis attributes the sex difference in COVID-19 severity to the transmembrane protease serine 2 (TMPRSS2) gene that is influenced by androgen/estrogen stimulation and facilitates the fusion of the viral and cellular membranes. ${ }^{32}$ 
medRxiv preprint doi: https://doi.org/10.1101/2020.06.25.20137323; this version posted June 27, 2020. The copyright holder for this preprint (which was not certified by peer review) is the author/funder, who has granted medRxiv a license to display the preprint in perpetuity.

All rights reserved. No reuse allowed without permission.

Although we found no association between obesity and severe COVID-19, other studies observed that morbid obesity (body mass index $\geq 40$ ) was a risk factor of disease severity. ${ }^{11,27}$ With regards to patients with neoplasm or a history of neoplasm, they were not found to have higher COVID-19 severity in our study. One Chinese study performed on 1,590 COVID-19 cases observed that the 18 patients with a history of cancer had a higher risk of disease severity in their crude analysis. ${ }^{32}$ However, these patients were older (63.1 years versus 48.7 years) and more likely to have been smokers (22\% versus $7 \%$ ) than the COVID-19 patients without a cancer history. ${ }^{33}$ A recent meta-analysis summarizing the existing literature on cancer and COVID-19 severity concluded that the current evidence on this association remains inconclusive. ${ }^{34}$ Likewise, the evidence of an association between asthma and COVID-19 severity is scarce and the previous studies were underpowered as they included few asthma cases among COVID-19 patients. ${ }^{6,15}$ Consistent with our findings, a recent analysis of UK biobank data concluded that asthma was associated with severe COVID-19 among 641 infected patients and that this association was driven by non-allergic asthma. ${ }^{17}$

Our epidemiological study is also the first to investigate the association of conditions such as vitamin D deficiency, pure hypercholesterolemia, osteoarthritis, and anemia with severe COVID-19 An analysis of UK biobank data examined the serum levels of vitamin D and the risk of infection with COVID-19 and found no association, while another study from the University of Chicago showed an increased risk of COVID-19 infection associated with vitamin D deficiency. ${ }^{18,35}$ However, none of the studies investigated the association of vitamin D with disease severity among patients who were already infected with SARS-CoV-2. ${ }^{18,35}$ In an ecological study, mortality rates among COVID-19 patients were compared among developed nations and it was suggested that countries with higher prevalence of vitamin D deficiency had 
medRxiv preprint doi: https://doi.org/10.1101/2020.06.25.20137323; this version posted June 27, 2020. The copyright holder for this preprint (which was not certified by peer review) is the author/funder, who has granted medRxiv a license to display the preprint in perpetuity.

All rights reserved. No reuse allowed without permission.

higher mortality rates. ${ }^{36}$ Yet, ecological studies do not include patient-level data and suffer from ecological fallacy, which is the assumption that factors associated with the national disease rates are associated with disease in individual patients. ${ }^{37}$ Nevertheless, there is reason to investigate Vitamin D status as a factor in disease progression. Vitamin D is well-known for its immunoregulatory properties; it can increase cellular immunity by stimulating antimicrobial peptides and could oppose cytokine storms induced by the innate immune responses. ${ }^{38,39}$ No published epidemiological study has also investigated whether high cholesterol is associated with higher risk of COVID-19 severity, although hypercholesterolemia is a major contributor to atherosclerosis and cardiovascular disease, which itself, is associated with severe COVID-19. ${ }^{40}$ Furthermore, high cholesterol might enhance the replication of SARS-CoV-2 in endothelial cells potentially causing acute vascular injury and triggering coagulopathies. ${ }^{41}$ No study has also examined the relationship of osteoarthritis and anemia with severe COVID-19. Osteoarthritis is a common joint disease, particularly prevalent in older adults; it is associated with various comorbidities and with an increased risk of mortality from cardiovascular diseases, diabetes and renal diseases. ${ }^{42,43}$ Anemia affects $5.6 \%$ of all Americans, but this prevalence is increased to more than $10 \%$ in Americans aged 65 or older. ${ }^{44,45}$ It is well-known to be a factor for poor prognosis in respiratory diseases such as COPD. ${ }^{46}$ In our study however, it is unclear whether anemia is a factor for severe COVID-19 or a consequence of the inflammation and cytokine production caused by the infection and leading to hemolytic anemia. ${ }^{46}$

Our study has limitations. It included only patients from a single health system in the Midwest of the U.S. and may not be generalizable to the overall American population. Our study design was observational; therefore, temporality and causality between certain factors (anemia, coagulation defects, and thrombocytopenia for instance) and COVID-19 severity cannot be 
established. Smoking status was missing for $22.8 \%$ of the COVID-19 participants. Vitamin D deficiency was defined using electronic medical records and data on the serum vitamin D levels were not available. Nonetheless, our study has major strengths, it was conducted in a large and racially/ethnically diverse sample of COVID-19 patients. It also included factors formerly understudied in COVID-19 such as vitamin D deficiency, pure hypercholesterolemia, osteoarthritis, and anemia.

In conclusion, the present study confirms previous reports that older age, non-Hispanic Black or Hispanic race/ethnicity, smoking, diabetes, COPD, chronic kidney disease, cardiovascular disease, coagulation defects, and thrombocytopenia are associated with severe COVID-19. It also identifies severe COVID-19 factors not previously reported such as vitamin D deficiency, pure hypercholesterolemia, osteoarthritis, and anemia. Our results are of public health relevance and have implications in the prioritization of COVID-19 patients at risk of severe disease and in the implementation of interventions to mitigate negative outcomes. Future studies should also evaluate whether vitamin D supplementation in COVID-19 patients with vitamin D deficiency might improve disease prognosis. 
medRxiv preprint doi: https://doi.org/10.1101/2020.06.25.20137323; this version posted June 27, 2020. The copyright holder for this preprint (which was not certified by peer review) is the author/funder, who has granted medRxiv a license to display the preprint in perpetuity.

\section{REFERENCES}

1. Phelan AL, Katz R, Gostin LO. The novel coronavirus originating in Wuhan, China: Challenges for global health governance. JAMA. 2020;323(8):709-710.

2. WHO Coronavirus Disease (COVID-19) Dashboard. https://covid19.who.int. Last accessed June 19, 2020.

3. Sampathkumar P, Temesgen Z, Smith TF, Thompson RL. SARS: Epidemiology, clinical presentation, management, and infection control measures. Mayo Clin Proc 2003;78(7):882-890.

4. Huang C, Wang Y, Li X, et al. Clinical features of patients infected with 2019 novel coronavirus in Wuhan, China. Lancet. 2020;395(10223):497-506.

5. Wang D, Hu B, Hu C, et al. Clinical characteristics of 138 hospitalized patients with 2019 novel coronavirus infected pneumonia in Wuhan, China. JAMA. 2020;323(11):1061-1069.

6. Li X, Xu S, Yu M, et al. Risk factors for severity and mortality in adult COVID-19 inpatients in Wuhan. J Allergy Clin Immunol. 2020;S0091-6749(20)30495-4.

7. Zhou F, Yu T, Du R, et al. Clinical course and risk factors for mortality of adult inpatients with COVID-19 in Wuhan, China: A retrospective cohort study. Lancet. 2020;395(10229):10541062.

8. Wu C, Chen X, Cai Y, et al. Risk factors associated with acute respiratory distress syndrome and death in patients with coronavirus disease 2019 pneumonia in Wuhan, China. JAMA Intern Med. 2020;e200994..

9. Bhargava A, Fukushima EA, Levine M, et al. Predictors for severe COVID-19 infection. Clin Infect Dis. 2020; ciaa674.

10. Du RH, Liang LR, Yang CQ, et al. Predictors of mortality for patients with COVID-19 pneumonia caused by SARS-CoV-2: A prospective cohort study. Eur Respir J. 2020;55(5):2000524.

11. Petrilli CM, Jones SA, Yang J, et al. Factors associated with hospital admission and critical illness among 5279 people with coronavirus disease 2019 in New York City: Prospective cohort study. BMJ. 2020;369:m1966.

12. Imam Z, Odish F, Gill I, et al. Older age and comorbidity are independent mortality predictors in a large cohort of 1305 COVID-19 patients in Michigan, United States. $J$ Intern Med. 2020;10.1111/joim.13119.

13. Akinbami L, Fryar C. Asthma prevalence by weight status among adults: United States, 2001-2014. NCHS data brief. 2016(239). 
medRxiv preprint doi: https://doi.org/10.1101/2020.06.25.20137323; this version posted June 27, 2020. The copyright holder for this preprint (which was not certified by peer review) is the author/funder, who has granted medRxiv a license to display the preprint in perpetuity. All rights reserved. No reuse allowed without permission.

14. Johnston SL. Asthma and COVID-19: Is asthma a risk factor for severe outcomes? Allergy. 2020;10.1111/all.14348.

15. Zhang J, Dong X, Cao Y, et al. Clinical characteristics of 140 patients infected with SARSCoV-2 in Wuhan, China. Allergy. 2020. Published ahead of print.

16. Morais-Almeida M, Pité H, Aguiar R, Ansotegui I, Bousquet J. Asthma and the coronavirus disease 2019 pandemic: A literature review. Int Arch Allergy Immunol. 2020:1-9.

17. Zhu Z, Hasegawa K, Ma B, Fujiogi M, Camargo Jr CA, Liang L. Association of asthma and its genetic predisposition with the risk of severe COVID-19. J Allergy Clin Immunol. 2020. Published ahead of print.

18. Meltzer DO, Best TJ, Zhang H, Vokes T, Arora V, Solway J. Association of vitamin D deficiency and treatment with COVID-19 incidence. medRxiv. 2020;2020.05.08.20095893.

19. Carroll MD, Fryar CD. Total and high-density lipoprotein cholesterol in adults: United States, 2015-2016. NCHS Data Brief. 2017;(290):1-8.

20. Liu X, Baylin A, Levy PD. Vitamin D deficiency and insufficiency among US adults: Prevalence, predictors and clinical implications. Br J Nutr. 2018;119(8):928-936.

21. Rentsch CT, Kidwai-Khan F, Tate JP, et al. Covid-19 by race and ethnicity: A national cohort study of 6 million united states veterans. medRxiv. 2020;2020.05.12.20099135.

22. McCullagh P. Generalized linear models. Routledge; 2018.

23. Patel AP, Paranjpe MD, Kathiresan NP, Rivas MA, Khera AV. Race, socioeconomic deprivation, and hospitalization for COVID-19 in English participants of a national biobank. medRxiv. 2020;2020.04.27.20082107.

24. Lassale C, Gaye B, Hamer M, Gale CR, Batty GD. Ethnic disparities in hospitalization for COVID-19: A community-based cohort study in the UK. medRxiv. 2020;2020.05.19.20106344.

25. Niedzwiedz CL, O'Donnell CA, Jani BD, et al. Ethnic and socioeconomic differences in SARS-CoV-2 infection: Prospective cohort study using UK biobank. BMC medicine. 2020;18:114.

26. Gold JA. Characteristics and clinical outcomes of adult patients hospitalized with COVID-19 Georgia, March 2020. MMWR Morb Mortal Wkly Rep. 2020;69(18):545-550.

27. Palaiodimos L, Kokkinidis DG, Li W, et al. Severe obesity is associated with higher inhospital mortality in a cohort of patients with COVID-19 in the Bronx, New York. Metab Clin Exp. 2020:154262. 
medRxiv preprint doi: https://doi.org/10.1101/2020.06.25.20137323; this version posted June 27, 2020. The copyright holder for this preprint (which was not certified by peer review) is the author/funder, who has granted medRxiv a license to display the preprint in perpetuity.

All rights reserved. No reuse allowed without permission.

28. Price-Haywood EG, Burton J, Fort D, Seoane L. Hospitalization and mortality among Black patients and White patients with COVID-19. N Engl J Med. 2020;NEJMsa2011686.

29. Stefan N, Birkenfeld AL, Schulze MB, Ludwig DS. Obesity and impaired metabolic health in patients with COVID-19. Nat Rev Endocrinol. 2020;16(7):341-342.

30. Yang X, Yang Q, Wang Y, et al. Thrombocytopenia and its association with mortality in patients with COVID-19. J Thromb Haemost. 2020;18(6):1469-1472.

31. Hanff TC, Harhay MO, Brown TS, Cohen JB, Mohareb AM. Is there an association between COVID-19 mortality and the renin-angiotensin system? a call for epidemiologic investigations. Clin Infect Dis. 2020; ciaa329.

32. Asselta R, Paraboschi EM, Mantovani A, Duga S. ACE2 and TMPRSS2 variants and expression as candidates to sex and country differences in COVID-19 severity in Italy. Aging. $2020 ; 12$.

33. Liang W, Guan W, Chen R, et al. Cancer patients in SARS-CoV-2 infection: A nationwide analysis in China. Lancet Oncol. 2020;21(3):335-337.

34. Desai A, Sachdeva S, Parekh T, Desai R. COVID-19 and cancer: Lessons from a pooled meta-analysis. JCO Glob Oncol. 2020;6:557-559.

35. Hastie CE, Mackay DF, Ho F, et al. Vitamin D concentrations and COVID-19 infection in UK biobank. Diabetes Metab Syndr. 2020;14(4):561-565.

36. Daneshkhah A, Agrawal V, Eshein A, Subramanian H, Roy HK, Backman V. The possible role of vitamin D in suppressing cytokine storm and associated mortality in COVID-19 patients. MedRxiv. 2020.

37. Pearce N. The ecological fallacy strikes back. J Epidemiol Community Health. 2000;54(5):326-327.

38. Grant WB, Lahore H, McDonnell SL, et al. Evidence that vitamin D supplementation could reduce risk of influenza and COVID-19 infections and deaths. Nutrients. 2020;12(4):988.

39. Mendy A, Cohn RD, Thorne PS. Endotoxin exposure, serum vitamin D, asthma and wheeze outcomes. Respir Med. 2016;114:61-66.

40. Perak AM, Ning H, De Ferranti SD, Gooding HC, Wilkins JT, Lloyd-Jones DM. Long-term risk of atherosclerotic cardiovascular disease in US adults with the familial hypercholesterolemia phenotype. Circulation. 2016;134(1):9-19.

41. Cao X, Yin R, Albrecht H, Fan D, Tan W. Cholesterol: A new game player accelerating endothelial injuries caused by SARS-CoV-2? Am J Physiol Endocrinol Metab. 2020. Published ahead of print. 
medRxiv preprint doi: https://doi.org/10.1101/2020.06.25.20137323; this version posted June 27, 2020. The copyright holder for this preprint (which was not certified by peer review) is the author/funder, who has granted medRxiv a license to display the preprint in perpetuity.

All rights reserved. No reuse allowed without permission.

42. Park J, Mendy A, Vieira ER. Various types of arthritis in the United States: Prevalence and age-related trends from 1999 to 2014. Am J Public Health. 2018;108(2):256-258.

43. Mendy A, Park J, Vieira ER. Osteoarthritis and risk of mortality in the USA: A populationbased cohort study. Int J Epidemiol. 2018;47(6):1821-1829.

44. Le $\mathrm{CH}$. The prevalence of anemia and moderate-severe anemia in the US population (NHANES 2003-2012). PLoS One. 2016;11(11):e0166635.

45. Guralnik JM, Eisenstaedt RS, Ferrucci L, Klein HG, Woodman RC. Prevalence of anemia in persons 65 years and older in the United States: Evidence for a high rate of unexplained anemia. Blood. 2004;104(8):2263-2268.

46. John M, Hoernig S, Doehner W, Okonko DD, Witt C, Anker SD. Anemia and inflammation in COPD. Chest. 2005;127(3):825-829. 
medRxiv preprint doi: https://doi.org/10.1101/2020.06.25.20137323; this version posted June 27, 2020. The copyright holder for this preprint (which was not certified by peer review) is the author/funder, who has granted medRxiv a license to display the preprint in perpetuity. All rights reserved. No reuse allowed without permission.

Table 1: Characteristics of study participants $(\mathrm{N}=689)$

\begin{tabular}{|c|c|c|c|c|c|c|c|}
\hline \multirow{2}{*}{ Characteristics } & \multirow{2}{*}{$\begin{array}{c}\text { All } \\
\text { Participants }\end{array}$} & \multicolumn{3}{|c|}{ Hospitalization } & \multicolumn{3}{|c|}{ Severe disease } \\
\hline & & No & Yes & P-value & No & Yes & P-value \\
\hline Prevalence, $\mathrm{N}(\%)$ & $689(100.0)$ & $473(68.7)$ & $216(31.3)$ & & $598(86.8)$ & $91(13.2)$ & \\
\hline \multicolumn{8}{|l|}{ Socio-demographic characteristics } \\
\hline Age, years, median (SE) & $49.5(1.3)$ & $44.38(1.2)$ & $60.3(2.0)$ & $<0.001$ & $47.2(1.3)$ & $60.5(3.4)$ & 0.001 \\
\hline Male sex, N (\%) & $365(53.0)$ & $245(51.8)$ & $120(55.6)$ & 0.359 & $319(53.3)$ & $46(50.5)$ & 0.619 \\
\hline Race/ethnicity, N (\%) & & & & $<0.001$ & & & $<0.001$ \\
\hline Non-Hispanic Whites & $201(29.2)$ & $138(29.2)$ & $63(29.2)$ & & $183(30.6)$ & $23(25.3)$ & \\
\hline Non-Hispanic Blacks & $176(25.5)$ & $91(19.2)$ & $85(39.3)$ & & $135(22.6)$ & $43(47.3)$ & \\
\hline Hispanics & $224(32.5)$ & $169(35.7)$ & $55(25.5)$ & & $187(31.3)$ & $23(23.3)$ & \\
\hline Other & $88(12.8)$ & 75 (15.9) & $13(6.0)$ & & $93(15.6)$ & $2(2.2)$ & \\
\hline Past and current smoker, ${ }^{\mathrm{a}} \mathrm{N}(\%)$ & $170(24.7)$ & $84(17.8)$ & $86(39.8)$ & $<0.001$ & $133(22.2)$ & $37(40.7)$ & $<0.001$ \\
\hline \multicolumn{8}{|l|}{ Comorbidities } \\
\hline Obesity, N (\%) & $128(18.6)$ & 75 (15.9) & $53(24.5)$ & 0.007 & $104(17.4)$ & $24(26.4)$ & 0.040 \\
\hline Diabetes, N (\%) & $170(24.7)$ & $76(16.1)$ & $94(43.5)$ & $<0.001$ & $124(20.7)$ & $46(50.5)$ & $<0.001$ \\
\hline Pure hypercholesterolemia, N (\%) & $20(2.9)$ & $2(0.4)$ & $18(8.3)$ & $<0.001$ & $10(1.7)$ & $10(11.9)$ & $<0.001$ \\
\hline Asthma, N (\%) & $70(10.2)$ & $34(7.2)$ & $36(16.7)$ & $<0.001$ & $47(7.9)$ & $23(25.3)$ & $<0.001$ \\
\hline COPD, $\mathrm{N}(\%)$ & $61(8.8)$ & 23 (4.9) & 38 (17.6) & $<0.001$ & $38(6.3)$ & $23(27.4)$ & $<0.001$ \\
\hline Chronic kidney disease, N (\%) & $81(11.8)$ & $24(5.1)$ & $57(26.4)$ & $<0.001$ & $46(7.7)$ & 35 38.5) & $<0.001$ \\
\hline Cardiovascular disease, $\mathrm{N}(\%)$ & $341(49.5)$ & $174(36.8)$ & $167(77.3)$ & $<0.001$ & $265(44.3)$ & $76(83.5)$ & $<0.001$ \\
\hline Neoplasm or history of neoplasm, N (\%) & $136(19.7)$ & $71(15.0)$ & $65(30.1)$ & $<0.001$ & $106(17.7)$ & $30(33.0)$ & $<0.001$ \\
\hline Osteoarthritis, N (\%) & $105(14.2)$ & $46(9.7)$ & $59(27.3)$ & $<0.001$ & $78(13.0)$ & $27(29.7)$ & $<0.001$ \\
\hline Vitamin D Deficiency, N (\%) & $89(12.9)$ & $44(9.3)$ & $45(20.8)$ & $<0.001$ & $66(11.0)$ & $23(25.3)$ & $<0.001$ \\
\hline \multicolumn{8}{|l|}{ Hematological disorders } \\
\hline Anemia, N (\%) & $176(25.5)$ & $82(17.3)$ & $94(43.5)$ & $<0.001$ & $123(20.6)$ & $53(58.2)$ & $<0.001$ \\
\hline Coagulation defect, $\mathrm{N}(\%)$ & $55(8.0)$ & $15(3.2)$ & $40(18.5)$ & $<0.001$ & $29(4.8)$ & $26(28.6)$ & $<0.001$ \\
\hline Thrombocytopenia, N (\%) & $37(5.4)$ & $9(1.9)$ & $28(13.0)$ & $<0.001$ & $18(3.0)$ & $19(20.9)$ & $<0.001$ \\
\hline
\end{tabular}

Abbreviations: SE, standard error; COPD, chronic obstructive pulmonary disease.

P-values for difference calculated using chi-square or Fisher's exact tests.

Severe disease defined as admission to intensive care unit or death.

a $22.8 \%$ of participants had missing data on smoking 
medRxiv preprint doi: https://doi.org/10.1101/2020.06.25.20137323; this version posted June 27, 2020. The copyright holder for this preprint (which was not certified by peer review) is the author/funder, who has granted medRxiv a license to display the preprint in perpetuity. All rights reserved. No reuse allowed without permission.

Table 2: Length of hospital stay (in days) overall and by characteristics of hospitalized study patients $(\mathrm{N}=191)$

\begin{tabular}{|c|c|c|c|}
\hline Characteristics & $\mathbf{N}$ & Median (IQR) & P-value \\
\hline All participants & 191 & $6.91(3.27,11.56)$ & \\
\hline \multicolumn{4}{|l|}{ Sociodemographic characteristics } \\
\hline Age groups & & & 0.005 \\
\hline$<60$ years & 92 & $5.25(2.50,11.08)$ & \\
\hline$\geq 60$ years & 99 & $7.76(5.01,12.44)$ & \\
\hline Sex & & & 0.056 \\
\hline Female & 84 & $5.77(3.01,9.76)$ & \\
\hline Male & 107 & $7.39(4.23,14.45)$ & \\
\hline Race/ethnicity & & & 0.001 \\
\hline Non-Hispanic Whites & 54 & $8.25(4.58,15.47)$ & \\
\hline Non-Hispanic Blacks & 72 & $7.76(4.36,11.93)$ & \\
\hline Hispanics & 54 & $4.62(2.35,8.68)$ & \\
\hline Other & 11 & $4.95(2.68,5.99)$ & \\
\hline Smoking $^{\mathrm{a}}$ & & & 0.117 \\
\hline Never smoker & 88 & $6.08(3.20,10.89)$ & \\
\hline Past and current smoker & 76 & $7.93(4.00,14.35)$ & \\
\hline \multicolumn{4}{|l|}{ Comorbidities } \\
\hline Obesity & & & 0.799 \\
\hline No & 143 & $6.70(3.33,12.00)$ & \\
\hline Yes & 48 & $6.93(3.25,10.72)$ & \\
\hline Diabetes & & & $<0.001$ \\
\hline No & 109 & $5.37(2.94,8.79)$ & \\
\hline Yes & 82 & $8.73(4.51,15.10)$ & \\
\hline Pure hypercholesterolemia & & & 0.065 \\
\hline No & 176 & $6.66(3.22,11.21)$ & \\
\hline Yes & 15 & $9.61(5.30,14.97)$ & \\
\hline Asthma & & & $<0.001$ \\
\hline No & 158 & $5.77(3.12,10.08)$ & \\
\hline Yes & 33 & $11.05(7.25,16.010$ & \\
\hline COPD & & & 0.002 \\
\hline No & 158 & $6.13(3.12,10.47)$ & \\
\hline Yes & 33 & $10.36(5.23,16.84)$ & \\
\hline Chronic kidney disease & & & 0.012 \\
\hline No & 146 & $5.84(3.03,10.47)$ & \\
\hline Yes & 45 & $8.57(5.11,15.17)$ & \\
\hline Cardiovascular disease & & & $<0.001$ \\
\hline No & 142 & $4.76(2.50,8.01)$ & \\
\hline Yes & 49 & $7.76(4.22,14.55)$ & \\
\hline Neoplasm or history of neoplasm & & & 0.004 \\
\hline No & 135 & $5.81(3.00,10.290$ & \\
\hline Yes & 56 & $8.28(5.12,16.00)$ & \\
\hline Osteoarthritis & & & 0.137 \\
\hline No & 139 & $6.19(3.04,11.03)$ & \\
\hline Yes & 52 & $7.17(4.96,14.35)$ & \\
\hline Vitamin D Deficiency & & & $<0.001$ \\
\hline No & 151 & $5.79(3.01,10.04)$ & \\
\hline Yes & 40 & $10.23(5.77,18.12)$ & \\
\hline \multicolumn{4}{|l|}{ Hematological disorders } \\
\hline Anemia & & & 0.003 \\
\hline No & 110 & $5.66(2.98,8.82)$ & \\
\hline Yes & 81 & $8.32(4.97,15.82)$ & \\
\hline Coagulation defect & & & 0.012 \\
\hline No & 160 & $6.13(3.24,10.72)$ & \\
\hline Yes & 31 & $10.56(5.05,21.75)$ & \\
\hline Thrombocytopenia & & & 0.003 \\
\hline No & 171 & $6.21(3.22,10.84)$ & \\
\hline Yes & 20 & $11.04(5.77,28.21)$ & \\
\hline
\end{tabular}

Abbreviations: IQR, interquartile range COPD, chronic obstructive pulmonary disease; N, number of participants in subgroups. P-values for difference calculated using Wilcoxon rank tests. 
medRxiv preprint doi: https://doi.org/10.1101/2020.06.25.20137323; this version posted June 27, 2020. The copyright holder for this preprint (which was not certified by peer review) is the author/funder, who has granted medRxiv a license to display the preprint in perpetuity. All rights reserved. No reuse allowed without permission.

Table 3: Risk Factors for hospitalization and disease severity in adjusted analysis $(\mathrm{N}=689)$

\begin{tabular}{|c|c|c|c|c|c|c|}
\hline \multirow{2}{*}{ Characteristics } & \multicolumn{3}{|c|}{ Hospitalization } & \multicolumn{3}{|c|}{ Disease severity } \\
\hline & $\mathbf{n} / \mathbf{N}$ & OR $(95 \% \mathrm{CI})$ & P-value & $\mathbf{n} / \mathbf{N}$ & OR $(95 \% \mathrm{CI})$ & P-value \\
\hline \multicolumn{7}{|l|}{ Socio-demographic characteristics } \\
\hline Age (per 10 years increase) & $216 / 689$ & $1.36(1.22,1.51)$ & $<0.001$ & $91 / 689$ & $1.27(1.11,1.47)$ & $<0.001$ \\
\hline Male sex & $120 / 365$ & $1.20(0.84,1.71)$ & 0.308 & $46 / 365$ & $1.15(0.72,1.84)$ & 0.558 \\
\hline \multicolumn{7}{|l|}{ Race/ethnicity } \\
\hline Non-Hispanic Whites & $63 / 201$ & Ref & & $23 / 201$ & Ref & \\
\hline Non-Hispanic Blacks & $85 / 176$ & $2.23(1.41,3.53)$ & $<0.001$ & $43 / 176$ & $3.15(1.71,5.79)$ & $<0.001$ \\
\hline Hispanics & $55 / 224$ & $1.91(1.11,3.29)$ & 0.020 & $23 / 224$ & $2.78(1.29,5.96)$ & 0.009 \\
\hline Other & $13 / 88$ & $0.59(0.29,1.18)$ & 0.136 & $2 / 88$ & $-{ }^{\mathrm{a}}$ & \\
\hline Ever Smoker & $86 / 170$ & $2.01(1.32,3.06)$ & $<0.001$ & $37 / 170$ & $1.65(0.96,2.83)$ & 0.558 \\
\hline \multicolumn{7}{|l|}{ Comorbidities } \\
\hline Obesity & $53 / 128$ & $1.40(0.89,2.22)$ & 0.149 & $24 / 128$ & $1.28(0.71,2.28)$ & 0.409 \\
\hline Diabetes & $94 / 170$ & $2.62(1.75,3.90)$ & $<0.001$ & $46 / 170$ & $2.60(1.58,4.28)$ & $<0.001$ \\
\hline Pure hypercholesterolemia & $18 / 20$ & $9.30(2.02,42.74)$ & 0.004 & $10 / 20$ & $3.47(1.30,9.27)$ & 0.013 \\
\hline Asthma & $36 / 70$ & $1.92(1.10,3.35)$ & 0.022 & $23 / 70$ & $3.11(1.67,5.80)$ & $<0.001$ \\
\hline COPD & $38 / 61$ & $1.69(0.90,3.19)$ & 0.105 & $23 / 61$ & $2.85(1.41,5.76)$ & $<0.001$ \\
\hline Chronic kidney disease & $57 / 81$ & $3.47(1.99,6.07)$ & $<0.001$ & $35 / 81$ & $5.35(2.92,9.80)$ & $<0.001$ \\
\hline Cardiovascular disease & $167 / 341$ & $4.39(2.75,7.01)$ & $<0.001$ & $76 / 341$ & $6.11(3.00,12.44)$ & $<0.001$ \\
\hline Neoplasm or history of neoplasm & $65 / 136$ & $1.42(0.91,2.20)$ & 0.124 & $30 / 136$ & $1.47(0.85,2.56)$ & 0.169 \\
\hline Osteoarthritis & $59 / 105$ & $1.95(1.19,3.19)$ & 0.008 & $27 / 105$ & $1.56(0.86,2.83)$ & 0.146 \\
\hline Vitamin D Deficiency & $45 / 89$ & $1.77(1.07,2.93)$ & 0.026 & $23 / 89$ & $1.95(1.07,3.56)$ & 0.029 \\
\hline \multicolumn{7}{|l|}{ Hematological disorders } \\
\hline Anemia & $94 / 176$ & $2.59(1.72,3.91)$ & $<0.001$ & $53 / 176$ & $4.12(2.44,6.95)$ & $<0.001$ \\
\hline Coagulation defect & $40 / 55$ & $4.90(2.52,9.56)$ & $<0.001$ & $26 / 55$ & $5.39(2.85,10.17)$ & $<0.001$ \\
\hline Thrombocytopenia & $28 / 37$ & $6.03(2.64,13.77)$ & $<0.001$ & $19 / 37$ & $6.52(3.10,13.73)$ & $<0.001$ \\
\hline
\end{tabular}

Abbreviations: OR, odds ratio; CI; confidence interval; COPD, chronic obstructive pulmonary disease; Ref, reference; $\mathrm{n} / \mathrm{N}$, cases/cases and non-cases in subgroup. Odds ratios calculated using logistic regression. Models adjusted for age, gender, race/ethnicity, and smoking.

$-{ }^{\mathrm{a}}$ odds ratio not computed 
medRxiv preprint doi: https://doi.org/10.1101/2020.06.25.20137323; this version posted June 27, 2020. The copyright holder for this preprint (which was not certified by peer review) is the author/funder, who has granted medRxiv a license to display the preprint in perpetuity. All rights reserved. No reuse allowed without permission.

Table 4: Factors associated with admission to ICU and death $(\mathrm{N}=689)$

\begin{tabular}{|c|c|c|c|c|c|c|}
\hline \multirow{2}{*}{ Characteristics } & \multicolumn{3}{|c|}{ Admission to ICU } & \multicolumn{3}{|c|}{ Death } \\
\hline & $\mathbf{n} / \mathbf{N}$ & OR $(95 \%$ CI $)$ & P-value & $\mathbf{n} / \mathbf{N}$ & OR $(95 \% \mathrm{CI})$ & P-value \\
\hline \multicolumn{7}{|l|}{ Sociodemographic characteristics } \\
\hline Age, per 10 year-increase & $65 / 689$ & $1.08(0.92,1.28)$ & 0.340 & $26 / 689$ & $1.94(1.47,2.58)$ & $<0.001$ \\
\hline Male sex & $32 / 365$ & $0.73(0.42,1.24)$ & 0.243 & $14 / 365$ & $1.36(0.58,3.17)$ & 0.480 \\
\hline \multicolumn{7}{|l|}{ Race/ethnicity } \\
\hline Non-Hispanic Whites & $11 / 201$ & Reference & & $9 / 201$ & Ref & \\
\hline Non-Hispanic Blacks & $29 / 176$ & $3.32(1.56,7.07)$ & 0.002 & $14 / 176$ & $3.44(1.32,9.00)$ & 0.012 \\
\hline Hispanics & $25 / 224$ & $3.44(1.42,8.34)$ & 0.006 & $1 / 224$ & $0.63(0.07,5.82)$ & 0.681 \\
\hline Other & $0 / 88$ & $-{ }^{\mathrm{a}}$ & & $2 / 88$ & $-{ }^{a}$ & \\
\hline Ever smoker & $27 / 170$ & $2.34(1.23,4.46)$ & 0.010 & $10 / 170$ & $0.82(0.33,2.01)$ & 0.659 \\
\hline \multicolumn{7}{|l|}{ Comorbidities } \\
\hline Obesity & $19 / 128$ & $1.47(0.76,2.83)$ & 0.250 & $5 / 128$ & $1.09(0.36,3.33)$ & 0.881 \\
\hline Diabetes & $34 / 170$ & $3.31(1.84,5.96)$ & $<0.001$ & $12 / 170$ & $1.79(0.75,4.27)$ & 0.193 \\
\hline Pure hypercholesterolemia & $7 / 20$ & $3.77(1.25,11.36)$ & 0.018 & $3 / 20$ & $-{ }^{a}$ & \\
\hline Asthma & $20 / 70$ & $4.33(2.18,8.58)$ & $<0.001$ & $3 / 70$ & $-^{\mathrm{a}}$ & \\
\hline COPD & $18 / 61$ & $4.26(1.87,9.77)$ & 0.001 & $5 / 61$ & $1.29(0.40,4.13)$ & 0.667 \\
\hline Chronic kidney disease & $22 / 81$ & $5.63(2.72,11.64)$ & $<0.001$ & $13 / 81$ & $4.48(1.81,11.08)$ & 0.001 \\
\hline Cardiovascular disease & $50 / 341$ & $5.59(2.57,12.14)$ & $<0.001$ & $0 / 341$ & $-{ }^{a}$ & \\
\hline Neoplasm or history of neoplasm & $21 / 139$ & $1.72(0.89,3.31)$ & 0.105 & $9 / 136$ & $1.06(0.42,2.66)$ & 0.900 \\
\hline Osteoarthritis & $19 / 105$ & $2.01(0.98,4.11)$ & 0.057 & $8 / 105$ & $1.10(0.42,2.89)$ & 0.854 \\
\hline Vitamin D deficiency & $18 / 89$ & $2.55(1.28,5.08)$ & 0.008 & $5 / 89$ & $1.08(0.37,3.17)$ & 0.889 \\
\hline \multicolumn{7}{|l|}{ Hematologic disorders } \\
\hline Anemia & $39 / 176$ & $5.19(2.80,9.65)$ & $<0.001$ & $14 / 176$ & $2.58(1.05,6.38)$ & 0.040 \\
\hline Coagulation defect & $17 / 55$ & $4.67(2.28,9.57)$ & $<0.001$ & $9 / 55$ & $8.81(3.11,24.98)$ & $<0.001$ \\
\hline Thrombocytopenia & $11 / 37$ & $5.14(2.18,12.09)$ & $<0.001$ & $8 / 37$ & $14.12(4.54,43.84)$ & $<0.001$ \\
\hline
\end{tabular}

Abbreviations: ICU, intensive care unit; OR, odds ratio; CI; confidence interval; COPD, chronic obstructive pulmonary disease; Ref, reference; $\mathrm{n} / \mathrm{N}$, cases/cases and non-cases in subgroup. Odds ratios calculated using multinomial logistic regression. Models adjusted for age, gender, race/ethnicity, and smoking.

$-{ }^{\mathrm{a}}$ odds ratios not computed. 
Table 5: Factors associated with length of hospital stay in days $(\mathrm{N}=191)$

\begin{tabular}{|c|c|c|}
\hline Characteristics & $\beta(95 \% \mathrm{CI})$ & P-value \\
\hline \multicolumn{3}{|l|}{ Sociodemographic characteristics } \\
\hline Age, per 10 years increase & $0.06(-0.01,0.12)$ & 0.107 \\
\hline Male sex & $0.39(0.16,0.62)$ & $<0.001$ \\
\hline \multicolumn{3}{|l|}{ Race/ethnicity } \\
\hline Non-Hispanic Whites & Ref & \\
\hline Non-Hispanic Blacks & $-0.09(-0.38,0.20)$ & 0.548 \\
\hline Hispanics & $-0.40(-0.74,-0.06)$ & 0.020 \\
\hline Other & $-0.65(-1.16,-0.14)$ & 0.013 \\
\hline Smoking $^{\mathrm{a}}$ & $0.01(-0.27,0.28)$ & 0.965 \\
\hline \multicolumn{3}{|l|}{ Comorbidities } \\
\hline Obesity & $-0.03(-0.31,0.25)$ & 0.834 \\
\hline Diabetes & $0.50(0.26,0.74)$ & $<0.001$ \\
\hline Pure hypercholesterolemia & $0.23(-0.20,0.66)$ & 0.300 \\
\hline Asthma & $0.50(0.20,0.81)$ & 0.001 \\
\hline COPD & $0.45(0.11,0.79)$ & 0.009 \\
\hline Chronic kidney disease & $0.17(-0.11,0.45)$ & 0.241 \\
\hline Cardiovascular disease & $0.40(0.10,0.70)$ & 0.008 \\
\hline Neoplasm or history of neoplasm & $0.19(-0.09,0.48)$ & 0.187 \\
\hline Osteoarthritis & $-0.13(-0.41,0.15)$ & 0.353 \\
\hline Vitamin D Deficiency & $0.47(0.20,0.75)$ & $<0.001$ \\
\hline \multicolumn{3}{|l|}{ Hematological disorders } \\
\hline Anemia & $0.38(0.14,0.62)$ & 0.002 \\
\hline Coagulation defect & $0.57(0.26,0.88)$ & $<0.001$ \\
\hline Thrombocytopenia & $0.67(0.30,1.03)$ & $<0.001$ \\
\hline
\end{tabular}

Abbreviations: $\beta$, regression coefficient; CI, confidence interval; COPD, chronic obstructive pulmonary disease; Ref, reference. Regression coefficients calculated using generalized linear models with a gamma distribution and a log link function. Models adjusted for age, gender, race/ethnicity, and smoking. 